\title{
POR QUE ESCREVE?
}

\author{
Antonio Cicero
}

Evidentemente, a pergunta não diz respeito à razão pela qual escrevo coisas tais como e-mails, currículos, listas de compras etc. O que se quer saber é por que escrevo as coisas pelas quais sou considerado escritor, isto é, por que escrevo poemas e ensaios. Ora, escrevo poemas por umas razões e ensaios por outras.

Mas há, de fato, uma razão pela qual escrevo tanto poemas quantoensaios: uma razão pela qual me tornei escritor. É que toda fala - inclusive a fala (o desenrolar) do pensamento - parece-me deficiente. É através da escrita que adquiro posse real do meu próprio pensamento.

Assim, para mim, a fala, quando não tem um sentido meramente utilitário, é uma espécie de protorrascunho da escrita.

No que diz respeito à teoria, isso quer dizer que não se consegue ser suficientemente preciso a menos que se use a escrita para tornar as ideias claras e distintas, como queria Descartes. Só a escrita permite a revisão, a análise e a correção do discurso. A fala é o domínio privilegiado da falácia retórica. A escrita falaciosa é a que está impregnada de fala. Através da escrita e da reescritura tento captar e eliminar ao máximo as falácias: em primeiro lugar, as do meu próprio pensamento; em segundo lugar, as dos pensamentos alheios.

Quanto à poesia, considero um poema como uma obra de arte elaborada com palavras. Ora, é a escrita que permite a elaboração mais cuidadosa. Para produzir uma obra de arte elaborada com palavras é preciso - tendo em Vista finalidades inteiramente diferentes das teóricas 
- rever, analisar e corrigir o seu esboço tantas vezes quantas se fizerem necessárias. A fala - inclusive, como eu já disse, a do pensamento constitui um protorrascunho. A partir desse protorrascunho, escreve-se o primeiro rascunho. É preciso passá-lo a limpo, isto é, retirar-lhe tudo o que não lhe pertence por direito, modificar o que deve ser modificado, adicionar o que falta, reduzi-lo ao que deve ser e apenas ao que deve ser. Nesse procedimento, vários rascunhos se sucedem. Sem a escrita isso seria impossível.

Mas talvez a pergunta seja: Por que escrevo poemas? A resposta se encontra guardada no meu poema Guardar. Seu final diz:

Por isso se escreve, por isso se diz, por isso se publica, por isso se declara e declama um poema:

Para guardá-lo:

Para que ele, por sua vez, guarde o que guarda:

Guarde o que quer que guarda um poema:

Por isso o lance do poema:

Por guardar-se o que se quer guardar. 